J. Lake Sci. (湖泊科学), 2013, 25(2):259-265

http: //www. jlakes.org. E-mail : jlakes@niglas.ac.cn

(C) 2013 by Journal of Lake Sciences

\title{
太湖康山湾示范区水生植物对水体氮、磷控制的适用性分析”
}

\author{
宋玉芝 ${ }^{1}$, 朱广伟 $^{2}$, 秦伯强 $^{2}$ \\ ( 1 : 南京信息工程大学环境科学与工程学院,南京 210044) \\ (2:中国科学院南京地理与湖泊研究所湖泊与环境国家重点实验室,南京 210008)
}

\begin{abstract}
摘 要: 为重建湖泊水生植被, 改善太湖局部水域水质, 在太湖康山湾示范区两个大型围隔进行了两种类型水生植物重 建. 通过 2010 年 8 月- 2011 年 8 月的现场采样及分析测定发现, 人工控制条件下, 浮叶植物荇菜和菱以及沉水植物马来 眼子菜的重建效果较好, 在其生长季节具有较高的覆盖度; 研究表明, 控制风浪及提高透明度是恢复水生植被的前提; 植 被重建区沉水植物氮、磷含量与浮叶植物差别不大, 但浮叶植物重建区水体氮、磷浓度的控制比沉水植物重建区好; 从经 济及水环境效益角度来看, 太湖敞水区的沿岸带由于风浪的控制比较困难, 恢复水生植被时, 应选择浮叶植物荇菜、菱、 沉水植物马来眼子菜等抗风浪能力强的物种. 本研究为太湖敞水区沿岸带的生态恢复方案制定提供了理论依据.
\end{abstract}

关键词: 水生植物; 氮磷控制; 适用性; 太湖

\section{Applicability analysis of aquatic macrophytes on controlling nitrogen and phosphorus from water in the Kangshan Bay demonstration area of Lake Taihu}

\author{
SONG Yuzhi ${ }^{1}$, ZHU Guangwei ${ }^{2} \&$ QIN Boqiang ${ }^{2}$ \\ (1:College of Environmental Science and Engineering, Nanjing University of Science Information and Technology, Nanjing \\ 210044, P. R. China) \\ (2: State Key Laboratory of Lake Science and Environment, Nanjing Institute of Geography and Limnology, Chinese Academy \\ of Sciences, Nanjing 210008 , P. R. China)
}

\begin{abstract}
In order to restore the aquatic vegetation and improve local water quality, reconstruction of two ecological types of aquatic plants were carried out in two large enclosures in the Kangshan Bay demonstration area of Lake Taihu. By annual investigation, results showed that floating-leaved aquatic plants such as Limnanthemun nymphoides and Trapa bicorni, and submerged plant such as Potamogeton macckianus grew better than other plants under controlled conditions. Their coverage was quite high during the growing season. Results also showed that, controlling wind-driven wave disturbance and improving water transparency were the prerequisite for aquatic vegetation restoration; there was no difference about $\mathrm{N}$ and $\mathrm{P}$ contents between submerged macrophyte and floating-leaved aquatic plants, but floating-leaved aquatic plants performed better than submerged macrophyte in removing water $\mathrm{N}$ and $\mathrm{P}$ content. Concerning the economic and environmental benefit, aquatic plants including L. nymphoides, T. bicorni and P. macckianus with powerful anti-wave ability could be selected as the pioneering species to rebuild the aquatic vegetation in the open area of Lake Taihu. This research provided theoretical basis for ecological restoration in the open littoral area of Lake Taihu.
\end{abstract}

Keywords: Aquatic macrophyte; control of $\mathrm{N}$ and P; applicability; Lake Taihu

湖泊是人类十分重要的水资源, 然而湖泊的富营养化已成为全球性环境问题 ${ }^{[1-2]}$. 通过生态工程, 实施 水生植物恢复等生物净化技术被广泛认为是湖泊富营养化治理的有效途径 ${ }^{\left[{ }^{3} 4\right]}$. 以往的水生植物恢复及其 环境效应研究试验中, 多数限于污染重的风浪影响较小的湖泊, 工作的重点在水生植物的种植本身, 在天然 富营养化湖泊风浪大的水域进行一定规模的试验并取得成功的报道比较少 ${ }^{[4]}$. 不同的水生植物在不同的生 活环境下生长特性和对水体氮、磷的影响效果不同 ${ }^{[4-5]}$. 对于湖泊水生植物恢复和生态修复, 首先需要做的

* 国家水体污染控制与治理科技重大专项项目 (2012ZX07101-010) 和国家自然科学基金项目 $(41071341,41230744$ ) 联 合资助. 2012-04-13 收稿;2012-08-22 收修改稿. 宋玉芝,女,1970 年生, 副教授;E-mail : syz70@ nuist. edu. cn. 
是研究该湖泊水生植物生长所需要的环境, 以及维持一个草型生态系统所需要的外部条件. 有些环境因素 是决定某一水域能否生长水生植物的根本要素, 如风浪. 关于太湖水生植物以及环境效益的研究较集中于 室内控制条件下以及野外调查 ${ }^{[5-8]}$, 而太湖的不同湖区环境因素差别很大, 决定水生植物存活及发展的环境 因素不一样, 水生植物对水体氮、磷的影响效果也存在差别 ${ }^{[9]}$. 本文以太湖康山湾风浪大蓝藻水华发生频繁 的区域作为水生植物重建的区域, 观察重建区水生高等植物存活及发展过程、测定水体的氮、磷营养指标的 变化, 旨在探讨在富营养化湖泊敞水区沿岸带恢复水生高等植物的过程, 建立合适的敞水区演替系列, 降低 和控制蓝藻生长所需氮、磷含量, 恢复重建健康的湖泊生态系统.

\section{1 材料与方法}

研究区位于太湖北部康山湾工程示范区 (图 1). 设有 2 个围隔和 1 个对照区, 每个围隔面积为 $1600 \mathrm{~m}^{2}$. 于 2010 年 3 月在浮叶植物重建区种植菱和荇菜, 菱采用种子撒播的方式, 荇菜采用幼苗移栽方式种植; 于 2010 年 7 月在沉水植物重建区种植伊乐藻、马来眼子菜、苦草、狐尾藻, 12 月种植蕰草, 2011 年 5 月种植狐 尾藻. 伊乐藻、马来眼子菜、苦草和狐尾藻采用幼苗移植,蕰草采用石芽撒播. 于 2010 年 8 月初至 2011 年 8 月底期间采样, 2010 年 8-10 月以及 2011 年 4-8 月, 每 $9 \mathrm{~d}$ 测定 1 次水生维管束植物分布 (覆盖度) 及苂光 参数, 每 $3 \mathrm{~d}$ 采集 1 次水样测定水体氮、磷等指标,每次 3 个重复; 2010 年 11 月-2011 年 2 月, 每个围隔每月 原位测定 1 次水生维束管植物分布 (覆盖度) 及苂光参数,每 $15 \mathrm{~d}$ 采集 1 次水样. 用水下饱和脉冲叶绿素苂 光仪 (Diving-PAM) 原位测定植物顶枝成熟叶暗适应 $20 \mathrm{~min}$ 后的最小苂光参数 $\left(F_{0}\right)$ 和最大苂光参数 $(F \mathrm{~m})^{[10]}$; 沉水植物用 $0.25 \mathrm{~m}^{2}$ 的网夹式采样器采集, 浮叶植物用样方法采集, 样品清洗后按种类分别在 $70^{\circ} \mathrm{C}$ 烘至恒重, 采用凯氏法和钿锑抗比色法测定植物体全氮和全磷 ${ }^{[11]}$; 水体氮、磷测定分别采用过硫酸钾氧 化-紫外分光光度法和过硫酸钾氧化-钼锑抗比色法 ${ }^{[11]}$. 所获得的数据采用 Excel 2003 和统计分析软件进行 统计分析,采用单因素方差分析 (One-way ANOVA) 比较不同数据组间的差异.
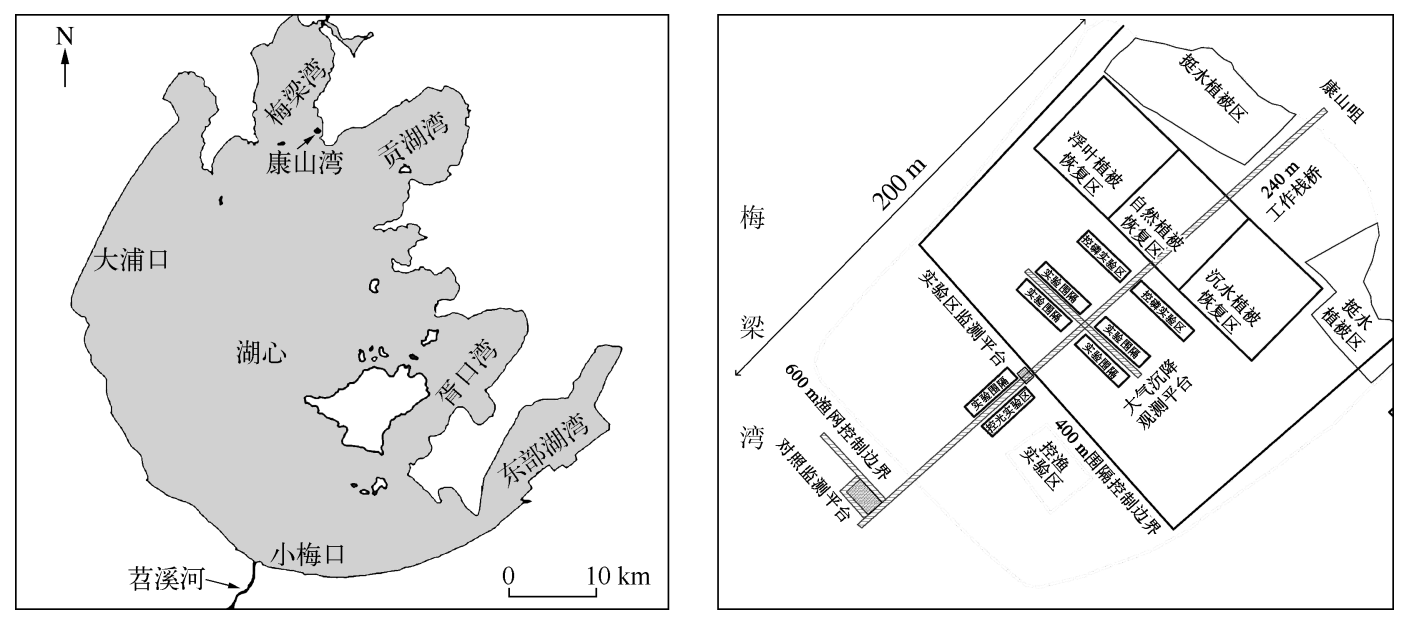

图 1 太湖康山湾工程示范区位置

Fig. 1 Location of Kangshan Bay demonstration area in Lake Taihu

\section{2 结果与分析}

\section{1 重建区水生植物的恢复}

2.1 .1 生长状况 用覆盖度来表示重建区水生植物生长状况. 沉水植物与浮叶植物覆盖度均存在季节变化 (图 2). 2010 年 8 月重建水生植物时浮叶植物覆盖度高达 $60 \%$, 随着时间的变化逐渐减小, 整个冬季覆盖度 几乎为零, 以后又有所增加, 但直到 2011 年 4 月前覆盖度增加的比较小, 4 月份后覆盖度开始迅速增加, 在 整个夏季以及中秋之前覆盖度高于 $40 \%$, 最高达 $97 \%$; 进一步分析浮叶植物重建区植物覆盖度不难发现, 重 
建水生植物当年 8-9 月,菱覆盖度显著高于荇菜 $(P<0.01), 10$ 月到次年 5 月初, 荇菜的覆盖度稍 高于菱,但覆盖率均较低. 次年的 5 月中旬至 8 月 份 7 月除外, 因收获了部分菱, 荇菜的覆盖度增 加), 菱覆盖率也显著高于荇菜 $(P<0.01)$ ( 图 2). 这说明在蓝藻生长季节, 浮叶植物覆盖度较高, 菱 在浮叶植物群落中较荇菜具有优势. 对于沉水植物 重建区, 沉水植物覆盖度在春季及夏季覆盖度相对 来说较高, 尤其是 4-5 月,最高可高达 $82 \%$, 秋、冬 季节覆盖度较小, 最小覆盖度不足 $1 \%$ ( 图 2 ); 进一 步分析沉水植物重建区植物覆盖度可知, 重建水生 植物当年, 水生植物生长季节观测发现只有马来眼 子菜存活, 在 8 月份, 其覆盖度变化范围为 $12 \%$ $18 \%, 9$ 月份开始, 其覆盖率有所下降, 冬季达到最 低 $(<1 \%)$. 次年 1 月菹草开始出现并迅速发展, 4 月份其覆盖度达到最高 (高达 77\%),5 月份迅速减 少最终消失. 狐尾藻次年 5 月份出现在沉水植物重 建区, 6-7 月生长迅速, 覆盖度达 15\% 左右, 8 月维

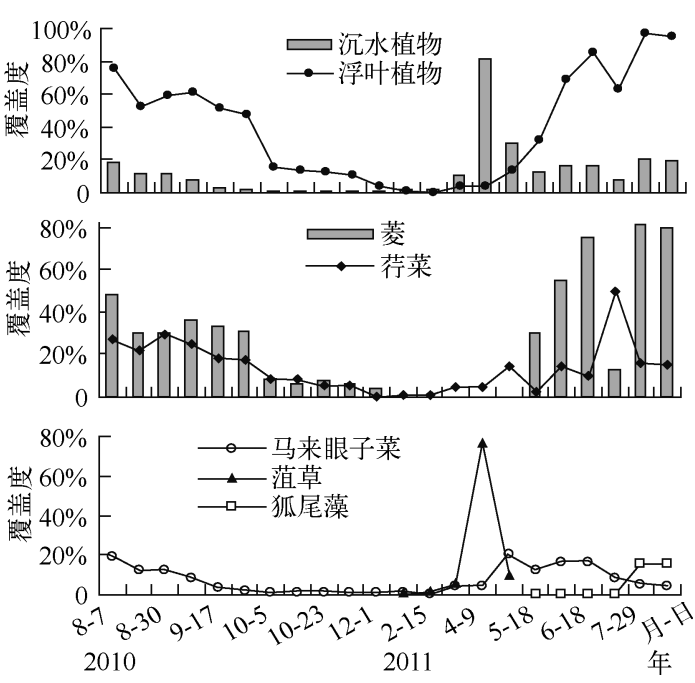

图 2 重建区水生植物覆盖度随时间的变化

Fig. 2 Temporal variation of macrophytes covers in reconstruction area

持这个水平 (图 2); 通过比较两种类型的水生植物重建区水生植物覆盖度发现, $1-5$ 月初, 沉水植物区植物 的覆盖率显著高于浮叶植物区浮叶植物 $(P<0.05)$, 其它月份, 沉水植物区植物的覆盖率显著低于浮叶植物 区的覆盖率 $(P<0.01)$ (图 2).

2.1 .2 生理状况 本文用水生植物 $\mathrm{PS}$ II 潜在光能转化效率 $\left(F_{\mathrm{V}} / F \mathrm{~m}, F_{\mathrm{V}} / F \mathrm{~m}=\left(F \mathrm{~m}-F_{\mathrm{o}}\right) / F_{\mathrm{m}}\right)$ 来反映水生 植物对环境因子的生理响应. 在水草生长季节, 浮叶植物 ( $5-9$ 月) 菱的最大量子产量 $(F \mathrm{~V} / F \mathrm{~m})$ 均值为 0.81 , 最低值为 0.76 , 最高值为 0.85 , 荇菜的 $F_{\mathrm{V}} / F \mathrm{~m}$ 均值为 0.83 , 最低值为 0.79 , 最高值为 0.83 , 荇菜 $F_{\mathrm{V}} / F \mathrm{~m}$ 最大值、最小值以及均值均高于菱相应的值 (表 1$)$; 对于沉水植物马来眼子菜 (5-9 月)、狐尾藻 (5-9 月) 以及䓚草 $\left(2-5\right.$ 月) 而言, 在其生长季节, 其 $F_{\mathrm{V}} / F \mathrm{~m}$ 的均值均小于浮叶植物菱和荇菜 (表 1$)$. 统计分析表明, 菱和荇菜 $F_{\mathrm{V}} / F \mathrm{~m}$ 差异不显著 $(P<0.05)$, 浮叶植物 $F_{\mathrm{V}} / F \mathrm{~m}$ 与沉水植物 $F_{\mathrm{V}} / F \mathrm{~m}$ 之间存在显著差异 $(P<0.01)$.

表 1 最大量子产量 $\left(F_{\mathrm{V}} / F \mathrm{~m}\right)$

Tab. 1 The maximum photochemical efficiency of PS II $\left(F_{\mathrm{V}} / F \mathrm{~m}\right)$

\begin{tabular}{cccccc}
\hline & 菱 $(5-9$ 月 $)$ & 荇菜 $(5-9$ 月) & 马来眼子菜 $(5-9$ 月 $)$ & 淔草 $(2-5$ 月 $)$ & 狐尾藻 $(5-9$ 月 $)$ \\
\hline 平均值 & 0.81 & 0.83 & 0.73 & 0.72 & 0.76 \\
标准偏差 & 0.02 & 0.03 & 0.04 & 0.08 & 0.02 \\
最小值 & 0.76 & 0.79 & 0.65 & 0.60 & 0.74 \\
最大值 & 0.85 & 0.87 & 0.78 & 0.77 & 0.79 \\
\hline
\end{tabular}

\section{2 重建区水生植物对水体氮、磷输出}

2.2 .1 重建区水生植物体内氮、磷含量 在植物生长季节, 浮叶植物总氮含量比沉水植物要高 (表 2), 但没 有显著差异 $(P<0.05)$. 浮叶植物菱总氮含量最高 $(25.57 \pm 3.32 \mathrm{mg} / \mathrm{g})$, 沉水植物狐尾藻最低 $(22.07 \pm 5.47$ $\mathrm{mg} / \mathrm{g}) ; \mathrm{P}$ 含量以沉水植物淔草最高 $(2.85 \pm 0.81 \mathrm{mg} / \mathrm{g})$, 浮叶植物荇菜最低 $(1.30 \pm 0.46 \mathrm{mg} / \mathrm{g})$; 水生植物体内 氮、磷含量与水体氮、磷浓度变化趋势并不一致.

2.2.2 收获植物输出氮磷量 从重建区水生植物体氮、磷含量及水生植物输出量不难计算出通过植物输出 所带走的氮、磷的量. 在重建区, 由于浮叶植物收获较多, 每平方米干物质重达 $932.04 \mathrm{~g}$, 而沉水植物区只收 获菹草, 每平方米干物质只有 $75 \mathrm{~g}$, 浮叶植物区通过收获浮叶植物的量远高于沉水植物区 (表 3 ). 因此, 通过 收获水生植物从浮叶植物重建区带走的氮、磷远高于沉水植物重建区. 而在重建区通过收割部分浮叶植物 
后, 对浮叶植物的覆盖度的影响较小, 覆盖度很快就恢复. 通过收获浮叶植物从浮叶植物重建区带走的总氮 量及总磷量分别为 $37.06 、 2.74 \mathrm{~kg}$, 其中通过收获荇菜及菱带走的总氮量分别为 $12.34 、 24.72 \mathrm{~kg}$, 总磷量分 别为 $0.68 、 2.06 \mathrm{~kg}$, 都远高于通过收割沉水植物而从沉水植物重见区带走的氮、磷 (总氮为 $2.86 \mathrm{~kg}$, 总磷为 $0.34 \mathrm{~kg})$. 由此可见,在水生植物重建初期,浮叶植物对氮、磷的输出效果要远高于沉水植物.

表 2 重建区水生植物氮、磷含量

Tab. 2 Nitrogen and phosphorus contents of macrophytes in reconstruction area

\begin{tabular}{lcrrrr}
\hline & 荇菜 & \multicolumn{1}{c}{ 菱 } & 马来眼子菜 & \multicolumn{1}{c}{ 狐尾藻 } & \multicolumn{1}{c}{ 淔草 } \\
\hline $\mathrm{TN} /(\mathrm{mg} / \mathrm{g})$ & $23.53 \pm 3.025$ & $25.57 \pm 3.32$ & $22.40 \pm 2.53$ & $22.07 \pm 5.47$ & $23.85 \pm 2.06$ \\
$\mathrm{TP} /(\mathrm{mg} / \mathrm{g})$ & $1.30 \pm 0.46$ & $2.13 \pm 1.45$ & $2.53 \pm 1.32$ & $2.55 \pm 0.76$ & $2.85 \pm 0.81$ \\
\hline
\end{tabular}

表 3 围隔区打捞水草输出氮、磷量

Tab. 3 Export of nitrogen and phosphorus from macrophyte in reconstruction area by harvest

\begin{tabular}{cccccc}
\hline 水生植物 & 鲜重 $/\left(\mathrm{g} / \mathrm{m}^{2}\right)$ & 干重 $/\left(\mathrm{g} / \mathrm{m}^{2}\right)$ & $\mathrm{TN} /\left(\mathrm{g} / \mathrm{m}^{2}\right)$ & $\mathrm{TP} /\left(\mathrm{g} / \mathrm{m}^{2}\right)$ & 收获时间 \\
\hline 荇菜 & 2393.75 & 327.73 & 7.71 & 0.43 & 2011 年 7 月 \\
菱 & 5106.25 & 604.31 & 15.45 & 1.29 & 2011 年 7 月 \\
蕰草 & 937.50 & 75.00 & 1.79 & 0.21 & 2011 年 4-6月 \\
\hline
\end{tabular}

\section{3 重建区水生植物对水体氮、磷的环境效应}

2.3.1 重建区水生植物对水体氮的环境效应 2010 年 8 月- 2011 年 8 月水生植物重建区及对照区水体总氮 浓度变化表明, 由于 2010 年水生植物的重建, 8-12 月 (除 11 月), 重建区水体中的总氮浓度较对照区高, 但 各区域月内水体总氮浓度波动均较大. 次年的 $1-8$ 月, 重建区水体中的总氮浓度较对照区低, 各区域月内 水体总氮浓度相对稳定, 沉水植物围隔区和浮叶植物围隔区平均总氮比对照区下降了 $16.49 \% 、 19.59 \%$. 在 水草生长季节 (5-8 月), 沉水植物围隔区和浮叶植物围隔区平均总氮比外围区下降了 $17.94 \% 、 29.90 \%$. 在水草生长季节,与其它月份相比, 7 月份沉水区总氮比外围区降低最大,降低 $26.68 \%$, 浮叶区降低 $27.49 \%$ (图 3a). 这说明在蓝藻生长季节, 浮叶植物重建区对水体总氮的控制效果要好于沉水植物控制区.

对于溶解性总氮而言, 其浓度在水生植物重建当年的 8 月, 水生植物重建区水体中的总氮浓度较对照 区略高, 但差异不显著 $(P<0.05) .11$ 月至次年 8 月, 水体溶解性总氮浓度均高于水生植物重建区. 与对照 区相比, 次年的 $1-8$ 月, 沉水植物围隔区和浮叶植物围隔区平均溶解性总氮下降了 $24.53 \% 、 22.92 \%$; 在水 草生长季节 $(5-8$ 月), 沉水植物围隔区和浮叶植物围隔区平均下降了 $27.37 \% 、 35.52 \%$; 在水草生长季节, 7 月份沉水区溶解性总氮与对照区相比下降最大, 降低了 $31.43 \%$, 浮叶区下降了 $28.07 \%$ (图 3b). 水体溶 解性总氮与水体中总氮浓度变化有一定的差异, 但在蓝藻生长季节 $(5-8$ 月) 总体效应是一致的, 即浮叶植 物重建区对水体溶解性总氮的控制效果要好于沉水植物控制区.

2.3.2 重建区水生植物对水体磷的环境效应 重建水生植物当年 8 月, 重建区水体中的总磷浓度较对照区 高 (图 3c). 次年的 $1-8$ 月, 浮叶植物围隔区平均总磷浓度比外围区下降了 $2.43 \%$, 沉水植物围隔区升高了 $1.81 \%$, 在水草生长季节 (5-8 月), 浮叶植物围隔区平均总磷浓度比对照区下降了 $0.82 \%$, 沉水植物围隔 区升高了 $1.95 \%, 7$ 月份总磷浮叶区比外围区降低最大, 降了 $25.02 \%$, 沉水植物围隔区比外围升高了 $7.17 \%$, 沉水植物围隔区水体磷浓度不仅不降低, 反而增加.

对于水体溶解性总磷而言, 重建水生植物 2010 年 8 月, 重建区水体中的溶解性总磷浓度较对照区略低, 但差别较小 (图 3d). 次年的 $1-8$ 月, 沉水植物、浮叶植物围隔区平均溶解性总磷浓度分别比外围区下降了 $25.42 \% 、 13.19 \%$, 在水草生长季节 (5-8 月), 沉水植物、浮叶植物围隔区平均溶解性总磷浓度分别比外围 区下降了 $6.63 \% 、 4.83 \%, 7$ 月溶解性总磷沉水植物、浮叶区比外围区降低了 $10.70 \% 、 23.43 \%$.

由此可见, 在蓝藻暴发季节 ( $7-8$ 月) 浮叶植物对重建区水体总磷控制效果比沉水植物好, 而对总磷的 控制上, 在重建水生植物次年, 浮叶植物生长季节一直好于沉水植物. 

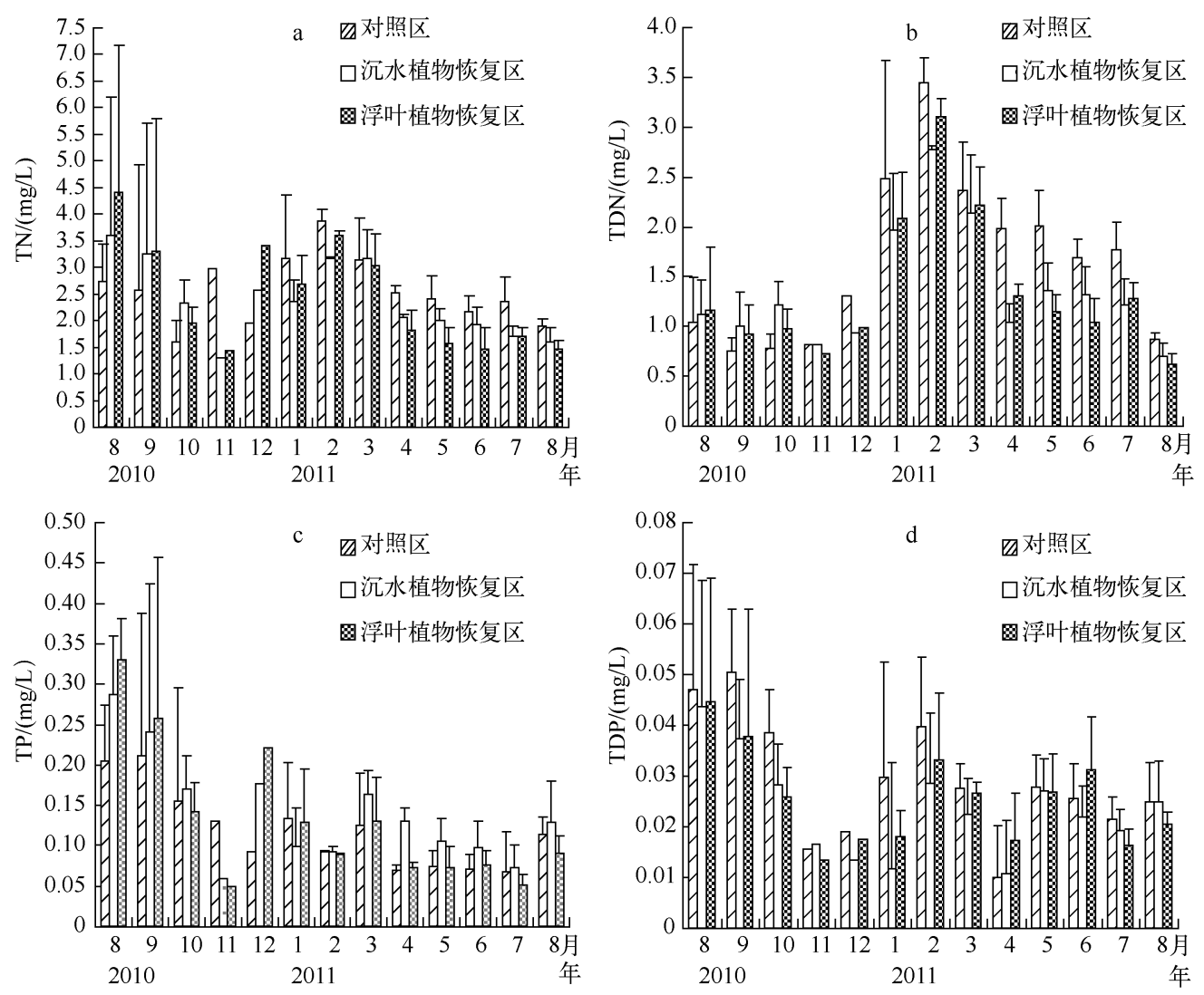

图 3 水体总氮 (a)、溶解性总氮 (b) 、总磷 (c) 和溶解性总磷 (d) 随时间的变化

Fig. 3 Temporal variation of total nitrogen(a), total dissolved nitrogen(b), total phosphorus(c) and total dissolved phosphorus $(\mathrm{d})$ in the water

\section{3 讨论}

\section{1 重建区水生植物恢复及优化}

经过 1 年多反复地在围隔区种植马来眼子菜、伊乐藻、金鱼藻、苦草和狐尾藻等太湖常见的沉水植物发 现, 伊乐藻、金鱼藻以及轮叶黑藻不适宜作为示范区的先锋种. 原位观测表明, 风浪稍大时, 伊乐藻、金鱼藻 和轮叶黑藻不仅会被连根拔起, 也容易使枝条折断, 飘浮在水面, 主要是因为伊乐藻、金鱼藻和轮叶黑藻等 沉水植物靠扦插不宜生根. 即使有些植物能生根、不易折断, 但较大的风浪会对水生植物产生生理伤害. 已 有的研究表明 ${ }^{[12]}: F_{\mathrm{V}} / F \mathrm{~m}$ 不受物种的影响, 非胁迫条件 下, 该参数的变化极小, 多数高等植物 $F_{\mathrm{V}} / F \mathrm{~m}$ 约为 0.83 ; 当植物受到环境胁迫时 $F_{\mathrm{V}} / F \mathrm{~m}$ 的值会明显降低. $F_{\mathrm{V}} / F \mathrm{~m}$ 反映了 PS II 原初光能转化效率或 PS II 潜在光能 转化效率. 图 4、5 是重建水生植物当年水生植物 PS II 潜 在光能转化效率 $\left(F_{\mathrm{V}} / F \mathrm{~m}\right)$ 以及每次采样前 $4 \mathrm{~d}$ 最大波 高. 重建水生植物当年 8 月 19 日采样前几天出现最大波 高, 接近太湖的平均波高 $0.5 \mathrm{~m}^{[13]}$ (图 5 ), 水生植物的 $F_{\mathrm{V}} / F \mathrm{~m}$ 显著下降 $(P<0.05)$, 马来眼子菜的 $F_{\mathrm{V}} / F_{\mathrm{m}}$ 接近 于 0.6 , 而浮叶植物 $F_{\mathrm{V}} / F_{\mathrm{m}}$ 在 0.7 左右 (图 4), 这说明大

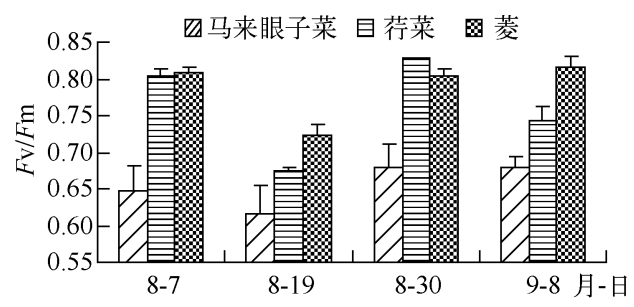

图 4 PS II 潜在光能转化效率 $\left(F_{\mathrm{V}} / F \mathrm{~m}\right)$ Fig. 4 Temporal variation of the maximum photochemical efficiency of PS II $\left(F_{\mathrm{V}} / F_{\mathrm{m}}\right)$ 


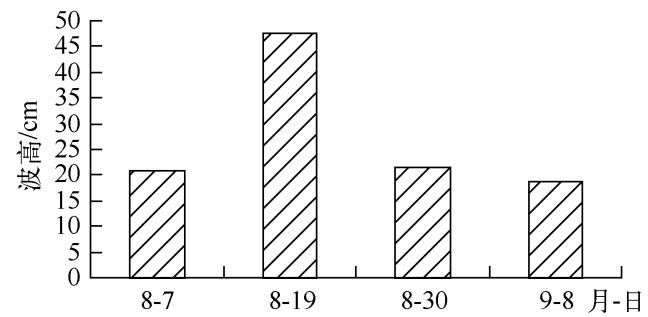

图 5 最大波高随时间的变化

Fig. 5 Temporal variation of the maximum wave height

的风浪对水生植物产生胁迫作用, 尤其是沉水植物. 此 外, 由于重建初期水体平均透明度不足 $45 \mathrm{~cm}$, 水深达 $1.5 \mathrm{~m}$ 以上, 光线不足也使这些生活在水底的沉水植物 很难成活. 而对于马来眼子菜、狐尾藻, 它们都是多年生 沉水冠层型植物, 地下茎比较发达, 通过整株移栽, 一方 面地下茎产生不定根, 另一方面由于植株较长, 叶主要 集中在上部,受水体透明度影响较小, 因此易成活.

蕰草通过鳞芽栽种, 在太湖站这种深度, 鳞芽存储 的养分足以使其生长到水面, 但不宜抗风浪,4 月后当 营养体达到一定量的时候, 受风浪的影响植株飘浮在水 面. 虽说狐尾藻和马来眼子菜同属多年生沉水冠层型植

物, 但由于穗花狐尾藻叶细小密集, 重建水生植物当年 8 月水体总悬浮物浓度平均为 $60.4 \mathrm{~g} / \mathrm{L}$, 最大高达 $179.0 \mathrm{~g} / \mathrm{L}$ (未发表的数据), 大量的悬浮物很快吸附在表面, 这使其光合作用降低 ${ }^{[14]}$, 影响生存. 次年 5 月移 植的狐尾藻可能由于水体悬浮物浓度降低而存活并有所发展 $(5$ 月水体总浮物浓度平均 $43.6 \mathrm{~g} / \mathrm{L}$ ( 未发表的 数据)). 本文观测表明, 浮叶植物重建区, 浮叶植物在风浪较大富营养化水体中恢复得很好, 这可能与浮叶 植物本身特性有关. 浮叶植物幼苗靠体内存储的养分足以生长到水面, 由于其受水体光影响小, 又比沉水植 物抗风浪能力强, 因此在重建当年就有比较高的覆盖度 $(>50 \%)$. 已有文献报道 ${ }^{[15]}$, 马来眼子菜、荇菜等有 一定的风浪适应能力, 往往生长在风浪相对较大的滨岸水域或分布在水生植被的外沿, 本文的观测结果与 其一致. 在风浪相对比较大的富营养化水体重建水生植物, 可以浮叶植物菱和荇菜以及沉水植物马来眼子 菜做先锋植物, 水体透明度改善后可引进苦草, 优化重建区水生植物的群落结构.

\section{2 重建区两种类型的水生植物控制氮、磷效应}

水生植物对水体氮、磷的控制效果, 一方面与水生植物对水体氮、磷吸收利用有关, 另一方面与水生植 物的其它环境效应 (吸附水体的悬浮物, 降低风浪, 抑制沉积物再悬浮等) 有关 ${ }^{[15-16]}$. 本文研究表明, 两种类 型的水生植物重建区水体总氮以及可溶性总氮浓度在水草生长季节 $(5-8$ 月) 均表现为: 对照区 > 沉水植 物区 $>$ 浮叶植物区, 这与重建区水生植物恢复有关. 本试验区中, 在重建沉水植物当年, 除马来眼子菜外, 其 它移植的植物没能存活, 而植物残体对水质影响很大 ${ }^{[16]}$, 这可能是水体总氮浓度表现为沉水植物区高于浮 叶植物区的原因之一; 此外, 由于此区的风浪扰动较大, 底部的营养盐物质悬浮到水体, 从而影响水体氮的 浓度 ${ }^{[16]}$. 对于水体磷而言, 在水草生长季节 (5-8 月), 总溶解性磷表现为: 沉水植物区 $<$ 浮叶植物区 $<$ 对照 区, 这与以往的研究结果一致, 但水体中总磷浓度与以往有差别, 表现为: 浮叶植物区 $<$ 对照区 $<$ 沉水植物 区, 这可能是由于沉水植物重建区, 降解的植物残体在风浪的扰动下影响水体总磷浓度 ${ }^{[17]}$.

\section{4 结论}

1) 太湖康山湾等风浪相对比较大的水体富营养化严重的敞水区, 以马来眼子菜、荇菜、菱可做此区域的 恢复先锋物种, 随后移种狐尾藻以苦草来优化群落结构.

2) 在植物生长季节, 重建区水生植物存在可有效地降低水体总氮的含量, 浮叶植物恢复区的效果比沉 水植物恢复区效果明显.

3) 在植物生长季节, 重建区水生植物存在可有效地降低水体中藻类生长所需要的有效磷的含量, 沉水 植物恢复区对有效磷的控制效果要好于浮叶植物恢复区. 基于成本及环境效益, 敞水区优先恢复浮叶植物, 环境条件改善后再逐步恢复苦草沉水植物.

致谢: 南京信息工程大学的杨美玖、王敏及韩华扬和中国科学院太湖湖泊生态系统研究站薛静深同志参与 采样及分析工作,在此表示诚挚的谢意.

\section{5 参考文献}

[ 1 ] Hasegawa H, Azizur Rahman M, Matsuda T et al. Effect of eutrophication on the distribution of arsenic species in eutroph- 
ic and mesotrophic lakes. Science of the Total Environment, $2009, \mathbf{4 0 7}(4)$ ):1418-1425.

[2] 朱广伟. 太湖富营养化现状及原因分析. 湖泊科学, 2008, 20(1):21-26.

[ 3 ] Nordstrom KF, Jackson NL. Physical processes and landforms on beaches in short fetch environments in estuaries, small lakes and reservoirs: A review. Earth-Science Reviews,2012,111 (1/2):232-247.

[ 4 ] Feldmann T, Nõges P. Factors controlling macrophyte distribution in large shallow Lake Võrtsjärv. Aquatic Botany, 2007, $87(1): 15-21$.

[ 5 ] 刘敬群, 陈家长. 在太湖中栽种沉水植物能使水变清吗? 生态学报, 2009, 29(5): 2764-2766.

[6] 王 华, 逢 勇, 刘申宝等. 沉水植物生长影响因子研究进展. 生态学报, 2008, 28(8): 3958-3968.

[ 7 ] 秦伯强. 富营养化湖泊开敞水域水质净化的生态工程试验研究. 环境科学学报, 2007, 27(1): 1-4.

[8] 雷泽湘, 徐德兰, 谢贻发等. 太湖水生植物氮磷与湖水和沉积物氮磷含量的关系. 植物生态学报, 2008, 32(2): $402-407$.

[ 9 ] 张晓晴, 陈求稳. 太湖水质时空特性及其与蓝藻水华的关系. 湖泊科学, 2011, 23( 3):339-347.

[10] Ralph PJ, Gademann R. Rapid light curves: A powerful tool to assess photosynthetic activity. Aquatic Botany, 2005,82 (3) : 222-237.

[11] 金相灿, 屠清瑛. 湖泊富营养化调查规范: 第 2 版. 北京: 中国环境科学出版社, 1990 .

[12] 韩博平, 韩志国, 付 翔. 藻类光合作用机理与模型. 北京: 科学出版社, 2003.

[13] 胡维平, 胡春华, 张发兵等. 太湖北部风浪波高计算模式观测分析. 湖泊科学, 2005, 17(1): 41-46.

[14] 李 强, 王国祥, 王文林等. 悬浮泥沙水体对穗花狐尾藻 (Myriophyllum spicatum L. ) 光合苂光特性的影响. 湖泊 科学, 2007, 19(2): 197-203.

[15] 金相灿, 颜昌宙, 许秋瑾. 太湖北岸湖滨带观测场水生植物群落特征及其影响因素分析. 湖泊科学, 2007,19 (2) : 151-157.

[16] 李文朝, 陈开宁, 吴庆龙等. 东太湖水生植物生物质腐烂分解实验. 湖泊科学, 2001, 13(4) : 331-336.

[17] 包裕尉, 卢少勇, 司 静等. 溶解氧和光照对狐尾藻衰亡释放氮磷碳的影响. 环境科学与技术, 2010, 33(2): 5-9. 